\title{
THE IMPORTANCE OF CREATIVE TASKS IN PHYSICS LESSONS
}

\section{Tamāra Brice}

Riga High School No. 41, Ogre State Gymnasium, RIMS, Latvia

E-mail: tamara.brice@gmail.com

\author{
Inga Brice \\ Ogre State Gymnasium, Latvia
}

\section{Introduction}

Everyone possesses curiosity and the desire to satisfy it. Each of us can become a scientist. Not only children, artists, musicians and writers are creative, but also scientists, businessmen etc. thinking creatively. Therefore, students should be more involved in the learning process, allowed to ask, to express their views and to think and act creatively. Pupils can learn by both reading and listening to what the other people say, as well as they can also learn by exploring - performing an experiment. This paper tries to understand what is creativity, and whether creative tasks are needed during physics lessons. This work explores what other authors have discussed about creativity as well as seek what is creativity and shares personal experience in the selection and implementation of a variety of creative tasks in school in physics lessons.

\section{Creativity}

The aim of the learning process is not only to help the student to acquire knowledge but also to learn the skills to explore, to think creatively and to draw conclusions. Creativity, exactly as the word itself suggests, means the ability to create something new. Creative thinking is extensive because not only children, artists, musicians and writers are creative, but also scientists, businessmen and even the heads of the country (Roze, 2011) are thinking creatively. Creativity and innovation helps to invent new thing and helps to solve a variety of technical issues, in other words, promotes social progress. The motivation is essential for the creative process since it significantly influences the quality of the pupils' achievements. Motivation is based on interest, pleasure and challenge which is obtained in the process. This stimulates to ask unusual questions, to take risks during the creative process and maintains the feeling of challenge to continue working, to find alternative solutions or unusual technical touches. The pupil is ready to continue the search, even if during the trial, disappointment and failure is experienced (Roze, 2011; Lieǵeniece, 2011). During a monotonous process one quickly loses motivation and teachers are not prepared to work with unmotivated children. 
J. Roze in his study (Roze, 2011) showed a certain connection between creativity and communication. More creative people are self-confident and have a better sense of humor, work well in a group, therefore they are more focused on communication. Creative people are trying to comprehend the core of a problem, to philosophize, to express original ideas. Communication helps to share their discoveries, makes it possible to deliver the information or ideas to others. On the other hand, Larisa Makḷova in her study about learning piano (Maklova, 2011) observed improvement of pupils' performance if the learning repertoire offered not only classical music but also a modern music pieces such as jazz. The pupil wants to see where the acquired knowledge can be applied in practice. Jazz and similar styles have become popular today. Special piano festival organization, that includes contemporary popular music, enable talented students to perform and boosts participants' motivation and creativity development. The audience is also more active and responds to the performance because the proposed repertoire is more dynamic and more easily perceptible.

Are talented children creative? Both of these words "talented" and "creative" have much in common, but they still are not synonyms. The talented pupil has a certain ability and characteristics which enhance motivation, for example, hardworking and self-sufficient. If the teaching material to a pupil seems too easy or too difficult, then he gets bored and quickly loses the motivation to learn (Lieǵeniece, 2011; Leitesa, 1996). Thus, this pupil must be challenged without overdoing it. Here is a crucial place where both teachers and parents often make mistakes by expecting outstanding achievements in all subjects and competitions. This may increase the fear of failure that crushes a child's positive view of himself. The positive self-assessment helps talented pupils to develop in a certain area while fear hinders chances of future development and even may lead to abandonment of the activity altogether.

\section{Examples of creative tasks}

The book "Physics: Exciting materials for classes" (Semke, 2004) describes a variety of ideas on how to create a physics curriculum more interesting for children. In order to encourage pupils to think for themselves during physics lessons and work creatively, while learning about sound, the pupils make a variety of instruments like drums, rattles, flutes and harps. The teacher may show some examples for ideas, but everyone chooses what kind of instrument to make and which of materials to use. Once the instrument is done the pupil shows it to the other pupils demonstrating this instrument and what kind of sound can be made using it. The pupil has to tell how it operates: where does the sound come from, what to do to act in order to make the sound quieter or louder, how to change the sound pitch. Some pupils even invented a creative names for their instruments. Other pupils will be happy to evaluate each other's work and chooses which one they liked best, stating the reasons why it is better. The activity of pupils and the resulting score can be seen in 
Figure 1. For Riga High School No. 41 this task was mandatory. In one of the classes, even though the work is done by the majority of pupils the interest rate is low and the instruments mostly created carelessly. The other class did a much better work and applied unusual ideas and devoted more time for the activity. For Ogre State Gymnasium this task was voluntary. Musical instruments produced significantly fewer pupils, but the work was done more thoroughly. Overall, there is a tendency for the higher the interest rate corresponding to the higher average grade for the assignment in class.

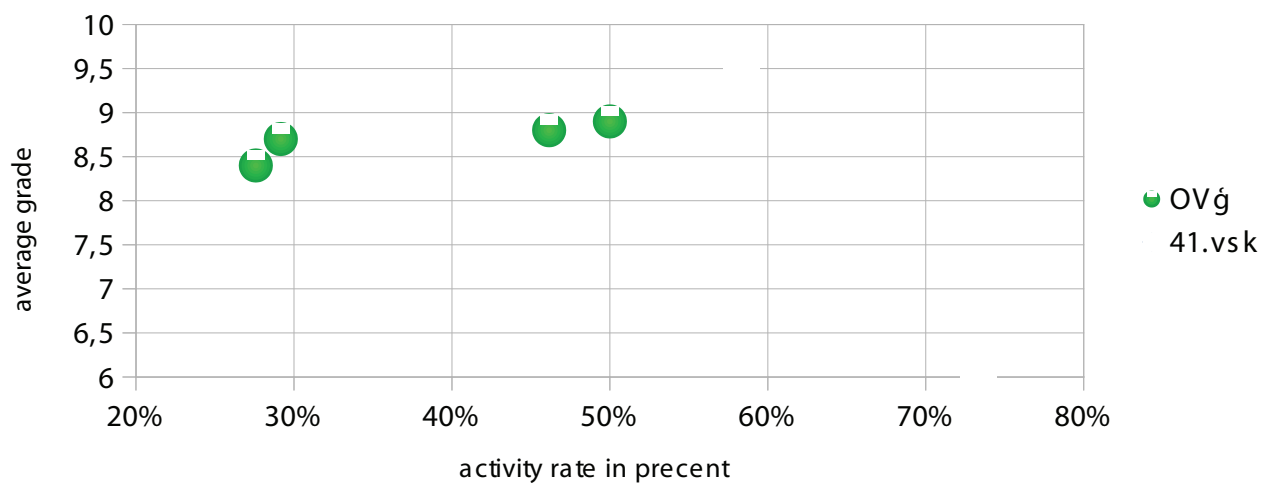

Figure 1 . The activity and the average grade for the task "musical instruments" $8^{\text {th }}$ grade for Ogre State Gymnasium, where the task was voluntary (green dots) and Riga High School No 41, where the task was mandatory (light blue dots).

Learning about light and shadow penumbra, $8^{\text {th }}$ grade pupils of Riga High School No. 41 proposed and themselves staged a shadow theatre. In a form of a fairy tale the example of the emergence of the shadow was shown. At the beginning of the process only 12 children from class were involved. In the next task "melting ice cream in differently colored containers" when learning about the heat the whole class joined in. Pupils drew graphs and made conclusions. To find out what affects the heating process using a variety of materials - glass, wood, metal, foam - pupils put the same mass of snow in various containers and came to the same concept of heat conducting. Pupils find it easier to solve tasks if they understand them and can link physical processes with the world around them. For example, to find the temperature after mixing hot and cold water, do it with a thermometer practically as well as theoretically by solving the equation. This helps to understand the taskwhat exactly are they trying to calculate. Pupils' interest grows as well as they become self-confident about their own performance, they will want to take part in such activities more. Positive self-assessment helps talented children to develop. In the second class, where children are weaker, pupils are trying to keep up. These pupils at home did similar experiments on evaporation. Students watched how different fluids evaporated for several days. All students took part in the physics afternoon, showing and explaining the experiments to $3^{\text {rd }}$ and $4^{\text {th }}$ grade pupils. The 
following afternoon the creation described in the "Physics: Exciting materials for classes" (Semke, 2004).

\section{Summing-up}

Pupils should be more involved in the learning process, allowed to ask, to express their views and to think or act creatively. The creative process is essential for motivation because it affects the quality of achievements. Motivation is based on interest, pleasure and a feeling of challenge which is gained doing an activity. The pupil wants to see where the acquired knowledge can be applied in practice. If the study material seems too easy or too difficult, it becomes boring. In order to encourage students to think for themselves during physics lessons learning about a sound they can make their own musical instruments. Pupils' own initiatives, such as shadow theatre, should be also allowed. Choose number of comprehensible experiments, such as in which coloured bowls the ice cream will melt faster. This link physical processes with the world around them and helps to understand. The interest in the subject grows and pupils become self-confident about their own work, they will want to take part and in next activities more pupils will be happy to engage.

\section{References}

Leitesa, N. S. (1996). Apdāvināto bērnu un pusaudžu psiholoǵija [The psychology of gifted children and adolescents]. Moscow: Academia.

Lieǵeniece, D. (2011). Viedoklis par sevi neīstenojušamies apdāvinātu bērnu problēmām: cēloṇi un risinājumi [The opinion about the problems of gifted children not developing their abilities: causes and solutions]. Radoša personība, IX. Riga: RPIVA.

Makḷova, L. (2011). Skolēnu kreativitātes attīstïbas veicināšana klavierspēles apguves procesā [Encouraging the development of pupils' creativity during piano lessons]. Radoša personība, IX. Riga: RPIVA.

Roze, J., Roze, J. (2011). Kreativitātes stila saistïba ar saskarsmes stiliem [The connection of the styles of creativity with the styles of communication]. Radoša personība, IX. Rīga:RPIVA.

Semke, A. I. (2004). Fizika: zanematilnaji materiali k urokam. 8 klass. [Physics: Exciting materials for classes. $8^{\text {th }}$ grade]. Moscow: NC ENAS. 